TITLE:

\title{
Nitrogen source utilization in co- existing canopy tree and dwarf bamboo in a northern hardwood forest in Japan
}

\section{$\operatorname{AUTHOR}(\mathrm{S}):$}

Tateno, Ryunosuke; Nakayama, Masataka; Yano, Midori; Fukuzawa, Karibu; Inagaki, Yoshiyuki; Koba, Keisuke; Ugawa, Shin

\section{CITATION:}

Tateno, Ryunosuke ...[et al]. Nitrogen source utilization in co-existing canopy tree and dwarf bamboo in a northern hardwood forest in Japan. Trees 2020, 34: 1047-1057

\section{ISSUE DATE:}

2020-8

URL:

http://hdl.handle.net/2433/252829

\section{RIGHT:}

This is a post-peer-review, pre-copyedit version of an article published in 'Trees'. The final authenticated version is available online at: https://doi.org/10.1007/s00468-020-01980-1.; The full-text file will be made open to the public on 25 April 2021 in accordance with publisher's 'Terms and Conditions for Self-Archiving'; この論文は出版社版でありません 。引用の際には出版社版をご確認ご利用ください。; This is not the published version. Please cite only the published version. 
1 Nitrogen source utilization in co-existing canopy tree and dwarf bamboo in a northern hardwood forest in Japan

3

4 Ryunosuke Tateno ${ }^{1 *}$, Masataka Nakayama ${ }^{2}$, Midori Yano ${ }^{3}$, Karibu Fukuzawa ${ }^{4}$, Yoshiyuki $5 \quad$ Inagaki $^{5}$, Keisuke Koba ${ }^{3}$, Shin Ugawa ${ }^{6}$

6

$7 \quad$ 1) Field Science Education and Research Center, Kyoto University, Kyoto 606-8502, 8 Japan

$9 \quad{ }^{2)}$ Graduate School of Agriculture, Kyoto University, Kyoto 606-8502, Japan

$10 \quad{ }^{3)}$ Center for Ecological Research, Kyoto University, Otsu 520-2113, Japan

4) Nakagawa Experimental Forest, Field Science Center for Northern Biosphere,

12 Hokkaido University, 486 Otoineppu, Otoineppu, Hokkaido 098-2501, Japan

13 5) Shikoku Research Center, Forestry and Forest Products Research Institute, 2-915

14 Asakuranishi, Kochi 780-8077, Japan

$15{ }^{6)}$ Faculty of Agriculture, Kagoshima University, 1-21-24 Korimoto, Kagoshima 890-

16 0065, Japan

$17 \quad$ ( ${ }^{*}$ Corresponding Author)

18 Ryunosuke Tateno

19 Field Science Education and Research Center, Kyoto University, 6068502, Kyoto, Japan

20 e-mail: rtateno@kais.kyoto-u.ac.jp

$21 \quad$ Tel \& Fax: +81-75-753-6441 
23 Key message: Understory dwarf bamboo mitigated soil N competition with co-existing canopy oak trees by foraging in deeper soils and increasing dependence on $\mathrm{N}$ forms that differ from those used by canopy trees.

\section{Abstract:}

Nitrogen $(\mathrm{N})$ competition among co-existing plant species utilizing different mycorrhiza types was explored through the investigation of $\mathrm{N}$ sources of oak trees and dwarf bamboo.

Vertical distribution of fine roots, soil $\mathrm{N}$ pools, $\delta^{15} \mathrm{~N}$ of leaves and possible soil $\mathrm{N}$ sources and nitrate reductase activity (NRA) were all quantified. The fine roots of canopy trees were more concentrated in the surface soils than roots of the understory dwarf bamboo. Soil $\mathrm{NH}_{4}{ }^{+}$and extractable organic $\mathrm{N}$ (EON) content (based on unit weight) decreased from the organic horizon (O horizon) to the deep soils, the size of the $\mathrm{NH}_{4}{ }^{+}$pool per unit volume increased with soil depth, and the EON was approximately constant. Soil $\mathrm{NO}_{3}{ }^{-}$ was not detected at any soil depth or was not significant in value, while $\mathrm{NO}_{3}{ }^{-}$captured by ion exchange resin (IER) buried at a $10 \mathrm{~cm}$ soil depth and net nitrification were observed via laboratory incubation at all soil depths. The $\delta^{15} \mathrm{~N}$ of the $\mathrm{NH}_{4}{ }^{+}$and EON pools increased with soil depth and the $\delta{ }^{15} \mathrm{~N}$ of $\mathrm{NO}_{3}{ }^{-}$of IER was lower than that of other $\mathrm{N}$ forms, except for the $\delta^{15} \mathrm{~N}$ of $\mathrm{NH}_{4}{ }^{+}$in the $\mathrm{O}$ horizon. Furthermore, root NRA tended to be lower in canopy trees than in the understory, implying lower dependency on $\mathrm{NO}_{3}{ }^{-}$by canopy trees. The pattern of root distribution and mycorrhizal fungi association of the understory vegetation (as well as the high root NRA) suggested that dependence on $\mathrm{N}$ in deeper soils was higher in understory plants than in canopy trees. These findings indicate that understory vegetation mitigate soil $\mathrm{N}$ competition against co-existing canopy trees via the use of alternative $\mathrm{N}$ sources. 
47 Keywords: Nitrate Reductase Activity, Nitrogen Source Utilization, Northern

48 Hardwood Forest, Mycorrhiza, Nitrogen Isotope

49 


\section{Introduction}

Nitrogen $(\mathrm{N})$ is the most important element limiting plant growth in many terrestrial ecosystems (Vitousek and Howarth 1991). Both inorganic $\mathrm{N}\left(\mathrm{NO}_{3}{ }^{-}\right.$and $\mathrm{NH}_{4}{ }^{+}$) and organic $\mathrm{N}$ are possible $\mathrm{N}$ sources for plants in forest soils. Co-existing plants compete for soil $\mathrm{N}$, and the vertical distribution of co-existing plant roots differs with the strength of belowground competition for soil resources (Cardinael et al. 2015). Utilization of $\mathrm{N}$ forms at different soil depths varies considerably among tree species, even among those growing at the same site (Nadelhoffer et al. 1996; Brearley 2013; Tanaka-Oda et al. 2016; Liu et al. 2018). Furthermore, $\mathrm{N}$ source preference varies among species (Nadelhoffer et al. 1996; Högberg 1997; Gherardi et al. 2013; Debiasi et al. 2019). N foraging strategy and $\mathrm{N}$ source utilization are therefore key for a better understanding of $\mathrm{N}$ competition among co-existing plants. 2000; Hobbie and Högberg 2012; Mayor et al. 2015). Ectomycorrhizal fungal species are typically stronger decomposers than arbuscular mycorrhiza fungal species due to the wider array of enzymes that they produce (Phillips et al. 2013). Soils dominated by ectomycorrhizal tree species have faster rates of decomposition of soil organic matter than soils dominated by arbuscular mycorrhizal tree species (Phillips et al. 2013), as well as greater carbon accumulation in the soil (Averill et al. 2014). Ectomycorrhizal and nonectomycorrhizal tree species have different $\mathrm{N}$ acquisition capacities according to their decomposition ability: ectomycorrhizal tree species rely primarily on organic $\mathrm{N}$ (Chalot and Brun 1998; Hodge et al. 2001; Courty et al. 2010; Smith and Smith 2011). Coexistence of competing plants could be partly explained by their mycorrhizal associate 
type.

Quercus crispula Blume (Oak) is a major component of the northern

hardwood forests of northern Japan (Hiura 2001) and is associated with both ectomycorrhizal and arbuscular mycorrhizal fungi (Obase et al. 2007). The understory dwarf bamboo species Sasa nipponica Makino et Shibata (Sasa) is a major understory species in the northern hardwood forest of eastern Hokkaido (Kayama and Koike 2018; Tateno et al. 2019), and Genus Sasa is known to associate with arbuscular mycorrhizal fungi (Fukuchi et al. 2011). The N source utilization patterns of co-existing canopy and understory plant species could differ according to their associated mycorrhizal fungi. However, details about $\mathrm{N}$ source utilization by co-existing canopy and understory species with different mycorrhizal associations have not yet been elucidated. We utilized a forest dominated by Q. crispula and S. nipponica as a model ecosystem to investigate the $\mathrm{N}$ source utilization of these co-existing species.

Determining the $\mathrm{N}$ source utilized by plants is a complex process, particularly in field conditions (Nadelhoffer et al. 1996; Nordin et al. 2001; Craine et al. 2015). The N isotope ratio in plant tissues reflects the isotopic composition of the $\mathrm{N}$ sources taken up by the plants (Nadelhoffer et al. 1996; Högberg 1997; Craine et al. 2015) because the $\mathrm{N}$ isotope ratio is rarely altered at the time of root $\mathrm{N}$ uptake under conditions of low $\mathrm{N}$ availability (Evans 2001). The $\mathrm{N}$ isotope ratio of plant tissues is affected by the form of $\mathrm{N}$ absorbed $\left(\mathrm{NH}_{4}{ }^{+}, \mathrm{NO}_{3}{ }^{-}\right.$, or dissolved organic $\left.\mathrm{N}\right)$, the type of mycorrhizal association (ectomycorrhiza or arbuscular mycorrhiza fungi), the presence or absence of symbiotic $\mathrm{N}$ fixation, the rooting depth, and the source of the $\mathrm{N}$ (i.e. soil $\mathrm{N}$ or rainfall $\mathrm{N}$ ) (Nadelhoffer et al. 1996; Högberg 1997; Hobbie et al. 2000; Hobbie and Högberg 2012; Brearley 2013; Craine et al. 2015). Recent advances in the denitrifier method (Sigman et al. 2001) have 


\section{Study site} 1978).

enabled the determination of $\mathrm{N}$ isotope ratios from small quantities of samples, which has led to more precise determination of the $\mathrm{N}$ isotope ratios of possible $\mathrm{N}$ sources, including soil extractable organic N (EON) (Koba et al. 2010).

a cool-temperate forest in northern Japan would utilize different $\mathrm{N}$ forms and from different source and soil depths as a strategy to mitigate $\mathrm{N}$ competition. We investigated the $\mathrm{N}$ source utilization of co-existing canopy tree species and understory species by measuring the vertical distribution of fine roots and quantifying the soil $\mathrm{N}$ pool to elucidate the $\mathrm{N}$ foraging mechanisms, determine foliar $\delta{ }^{15} \mathrm{~N}$, and identify possible soil $\mathrm{N}$ sources including EON, which is less reported (Houlton et al. 2007; Takebayashi et al. 2010; Koba et al. 2010). We also measured nitrate reductase activity (NRA) for both species for use as an indicator of $\mathrm{NO}_{3}{ }^{-}$uptake and use by the plants (Lee and Stewart

\section{Materials and methods}

The study was conducted in a cool temperate deciduous natural forest in the Shibecha Branch of the Hokkaido Forest Research Station, Field Science Education and Research Center, Kyoto University, Japan ( $\left.43^{\circ} 24.2^{\prime} \mathrm{N}, 144^{\circ} 38.5^{\prime} \mathrm{E}\right)$. The study site was dominated by an Oak canopy layer and the understory was dominated by dwarf bamboo Sasa (Nakayama and Tateno 2018; Tateno et al. 2019). The diameter at breast height of canopy trees of study site were about $30 \mathrm{~cm}$ and the height of Sasa was between 80-100 
$122 \mathrm{~cm}$ (Tateno et al. 2019). The annual litterfall production of the study site was $493.3 \mathrm{~g}$

$123 \mathrm{~m}^{-2}$ year $^{-1}$ and the biomass of current year shoots and overwinter shoots of Sasa was

124219.7 and $60.0 \mathrm{~g} \mathrm{~m}^{-2}$ year $^{-1}$, respectively (Tateno et al. 2019). The photosynthetic rates

125 of current year shade shoots of genus Sasa species tend to be higher in the late autumn,

126 when the forest canopy is more open than in mid-summer (Lei and Koike 1998).

127 However, the $\mathrm{N}$ content of above-ground current shoots of Sasa reached a maximum

128 from July to August before decreasing gradually until the end of November at this study

129 site (Tateno et al. 2019). Likewise, the $\mathrm{N}$ content of current shoots in oak trees reached

130 a maximum value from July to August (Tateno et al. 2019).

131 The mean annual precipitation and air temperature (1986-2015) were $1189 \mathrm{~mm}$

132 and $6.3^{\circ} \mathrm{C}$, respectively, according to data from a meteorological station about $9 \mathrm{~km}$

133 from the study site ( $\left.43^{\circ} 19.46^{\prime} \mathrm{N}, 144^{\circ} 36.8^{\prime} \mathrm{E}\right)$. The soils of the study site were

134 characterized as andosols (IUSS Working group WRB 2015). Details of soil properties

135 of the study site have been extensively reported elsewhere (Hosokawa et al. 2017; Isobe

136 et al. 2018; Watanabe et al. 2019).

\section{Plant sampling}

140 We established a $20 \times 20 \mathrm{~m}$ study plot for the sampling of soils and plants. Seven healthy

141 Oak canopy trees within the plot were selected for determining the $\mathrm{N}$ isotope ratio from

142 the leaves. On July 30, 2016, twigs with at least ten current year shoots, were harvested

143 from the crown of each tree using a pole pruner. Three Sasa current shoots were

144 concurrently collected from seven points close to the Oak sampling trees within the study

145 plot, and were composited into one sample for each point. The samples were maintained 
146 at a cool temperature during transport to the laboratory and separated into leaves and

147 twigs. Leaves were immediately washed with ion-exchanged water to avoid dry 148 deposition effects on the $\mathrm{N}$ isotope ratio. Leaf samples were milled after oven drying at $60^{\circ} \mathrm{C}$ and stored until isotope measurement.

\section{Fine root sampling}

153 Soil samples along five soil profiles were collected with a cylindrical soil corer $\left(20 \mathrm{~cm}^{2}\right.$ in area) at depths of $0-5,5-10,10-15,15-20,20-25,25-30,30-35,35-40,40-45$, and 45$50 \mathrm{~cm}$ on August 23, 2017. Five samples $(20 \times 20 \mathrm{~cm})$ from the $\mathrm{O}$ horizon were also collected in the area just above each soil sampling profile. Roots in the soil cores and the collected O horizon were wet-sieved using $0.5 \mathrm{~mm}$ and $2 \mathrm{~mm}$ mesh. Fine roots $(<2 \mathrm{~mm}$ in diameter) were hand sorted with tweezers under a stereoscopic microscope based on their morphology (existence of ectomycorrhiza and/or branching pattern), color, and surface condition to separate by species (Oak and Sasa) and condition (living or dead root). Fine roots of other species were not identified within the samples. After sorting, the roots were dried at $70{ }^{\circ} \mathrm{C}$ for $72 \mathrm{~h}$ and the dry mass was measured. During the fine root sorting, we measured the ECM mycorrhizal infection rate (\%, mycorrhizal root tips / total root tips $\times 100$ ) of Oak by counting all infected and non-infected root tips in the samples under a stereoscopic microscope.

To compare with the isotopic value and the quantity of a given $\mathrm{N}$ source, the fine root mass densities $\left(\mathrm{mg} \mathrm{cm}^{-3}\right.$ ) of the $\mathrm{O}$ horizon, and the $0-10,10-30$, and $30-50 \mathrm{~cm}$ layers of mineral soils were calculated for each soil profile by summing up the fine root mass divided by the sampling area and each depth interval. For the $\mathrm{O}$ horizon, the average depth 
170 value of the FH (fermented and humic) horizon (i.e. O horizon excluding surface litter 171 horizon $)$ in this study site $(2.9 \pm 0.9 \mathrm{~cm}$, average $\pm \mathrm{SD}, n=5)$ was used for fine root mass densities, because fine roots were not found in the litter horizon.

\section{Soil sampling and chemical analysis}

For isotope measurements of soil $\mathrm{N}$ species, we collected soil from the four centers of the $10 \times 10 \mathrm{~m}$ subplots in the study plot $(20 \times 20 \mathrm{~m})$ using a soil auger at depths of $0-10,10$ 30, and 30-50 cm from four soil profiles on July 30, 2016. The $\mathrm{O}$ horizon just above the soil sampling profiles was also collected. The quantities of $\mathrm{NO}_{3}{ }^{-}, \mathrm{NH}_{4}{ }^{+}$, and total extractable $\mathrm{N}$ were determined by extraction from $8 \mathrm{~g}$ of wet soil with $80 \mathrm{ml}$ of $0.5 \mathrm{M}$ $\mathrm{K}_{2} \mathrm{SO}_{4}$ solution by shaking for $1 \mathrm{~h}$. After shaking, solutions were centrifuged (3000 rpm for $10 \mathrm{~min}$ ) and then filtered by glass fiber filters (GF/F; Whatman). The $\mathrm{K}_{2} \mathrm{SO}_{4}$ and glass fiber filters were pre-combusted at $450{ }^{\circ} \mathrm{C}$ for $4 \mathrm{~h}$ before use to remove contamination. Extracts were stored in a freezer $\left(-20^{\circ} \mathrm{C}\right)$ until chemical and isotope analysis. Soil moisture content was measured using sub-soil samples. during laboratory incubation, we collected soil at depths of $0-10,10-20,20-30,30-40$, and $40-50 \mathrm{~cm}$ from six soil profiles using a cylindrical soil core $\left(20 \mathrm{~cm}^{2}\right.$ in area) on August 23, 2017. Samples were extracted using $2 \mathrm{M} \mathrm{KCl}$ solution and shaken for $1 \mathrm{~h}$. Subsamples were incubated aerobically at $25{ }^{\circ} \mathrm{C}$ for $28 \mathrm{~d}$ in an incubator. Incubated soils were also extracted using $2 \mathrm{M} \mathrm{KCl}$ solution and shaken for $1 \mathrm{~h}$. The net change rates of $\mathrm{NH}_{4}{ }^{+}$, $\mathrm{NO}_{3}{ }^{-}$, and EON were calculated by subtracting the pool size of each $\mathrm{N}$ species after the incubation period (28 d) from the initial pool size and dividing by the incubation period. 
194 We simultaneously collected three samples from 0-10, 10-20, 20-30, 30-40, and 40-50 cm depths for determination of soil bulk density. Collected soils were sieved using a 2 $\mathrm{mm}$ mesh screen and weighed after drying at $105^{\circ} \mathrm{C}$. Five $\mathrm{O}$ horizon samples were also collected from a $20 \times 20 \mathrm{~cm}$ area to assess pools in the $\mathrm{O}$ horizon. Collected samples were weighed after drying at $105^{\circ} \mathrm{C}$.

The concentrations of $\mathrm{NH}_{4}^{+}$and $\mathrm{NO}_{3}^{-}$in the extracts were analyzed colorimetrically by the indophenol blue method and by diazotization after reduction to $\mathrm{NO}_{2}{ }^{-}$with zinc powder, respectively (Keeney and Nelson 1982). The total extractable $\mathrm{N}$ was converted into $\mathrm{NO}_{3}{ }^{-}-\mathrm{N}$ using the persulfate oxidation procedure and analyzed colorimetrically. The EON concentration was calculated by subtracting the inorganic $\mathrm{N}$ $204\left(\mathrm{NH}_{4}{ }^{+}-\mathrm{N}\right.$ and $\left.\mathrm{NO}_{3}{ }^{-}-\mathrm{N}\right)$ concentrations from the total extractable $\mathrm{N}$ concentration. To compare the isotopic value, the pool size and net change rate of $\mathrm{N}$ species in the $\mathrm{O}$ horizon, and the $0-10,10-30$, and 30-50 cm layers of mineral soils were weight-averaged for each soil profile using the bulk density and were expressed as soil weight (mgN kg soil ${ }^{-1}$ ) and volume $\left(\mathrm{gN} \mathrm{m}^{-3}\right)$.

Soil $\mathrm{NO}_{3}{ }^{-}$was captured by ionic resin capsules containing about $1 \mathrm{~g}$ of mixed 210 ion exchange resins (PST-2, Unibest, Bozeman, MT), which were placed at a depth of 10 $211 \mathrm{~cm}$ in the mineral soil. Similar resin capsules have been used to assess in-situ net N 212 mineralization and nitrification over a specific time period (e.g. DeLuca et al., 2002). Five resin capsules were placed at a depth of $10 \mathrm{~cm}$ in the mineral soil on July 30, 2016 and collected on July 9, 2017. The collected capsules were washed with distilled water to remove adhering soils. The resin capsules were extracted for $\mathrm{NO}_{3}{ }^{-}-\mathrm{N}$ analysis by shaking thrice in $10 \mathrm{ml}$ of $2 \mathrm{M} \mathrm{KCl}$ for $1 \mathrm{~h}$. 
The $\delta^{15} \mathrm{~N}$ values of $\mathrm{NO}_{3}{ }^{-}$in the soil and the ion exchange resin capsules extracts were measured by the denitrifier method (Sigman et al. 2001; Casciotti et al. 2002; Koba et al. 2010, 2012). The $\mathrm{NO}_{3}{ }^{-}$in the soil and resin extract was converted into $\mathrm{N}_{2} \mathrm{O}$ using a denitrifier (Pseudomonas aureofaciens) lacking the gene coding for $\mathrm{N}_{2} \mathrm{O}$ reductase. The $\delta^{15} \mathrm{~N}$ value of $\mathrm{NH}_{4}{ }^{+}$in the soil extracts was measured using the denitrifier method after ammonia diffusion (Holmes et al. 1998) followed by the persulfate oxidation method (Koba et al. 2010, 2012) to convert the sample $\mathrm{NH}_{4}{ }^{+}$to $\mathrm{N}_{2} \mathrm{O}$ via $\mathrm{NO}_{3}{ }^{-}$. The $\delta^{15} \mathrm{~N}$ values of total dissolved $\mathrm{N}$ were determined by analyzing the persulfate-digested samples with the denitrifier method (Koba et al. 2010, 2012). The $\delta^{15} \mathrm{~N}$ of the $\mathrm{N}_{2} \mathrm{O}$ produced by the denitrifier was analyzed using an isotope ratio mass spectrometer (20-22 IRMS equipped with Cryoprep and GC; Sercon Ltd., Cheshire, UK) with the protocol defined by McIlvin and Casciotti (2011). The natural abundance of ${ }^{15} \mathrm{~N}$ was reported as $\delta^{15} \mathrm{~N}$ :

$$
\delta^{15} \mathrm{~N}=\left[\left(\mathrm{R}_{\text {sample }}-\mathrm{R}_{\text {standard }}\right) / \mathrm{R}_{\text {standard }}\right] \text {, }
$$

233 where $\mathrm{R}={ }^{15} \mathrm{~N} /{ }^{14} \mathrm{~N}$ and the standard is atmospheric N2. Calibrated in-house standards DL-alanine ( $\delta^{15} \mathrm{~N}=-1.7 \%$ ), glycine $\left(\delta^{15} \mathrm{~N}=+10.0 \%\right.$ ), and L-histidine $\left(\delta^{15} \mathrm{~N}=-8.0 \%\right.$ ); international $\mathrm{NH}_{4}^{+}$isotopic standards USGS25, USGS26, and IAEA-N-2; and international $\mathrm{NO}_{3}{ }^{-}$isotopic standards IAEA-NO-3, USGS32, and USGS34 were used for the $\delta^{15} \mathrm{~N}$ of total dissolved $\mathrm{N}, \mathrm{NH}_{4}{ }^{+}$, and $\mathrm{NO}_{3}{ }^{-}$calibration, respectively. The average standard deviations of replicate measurements of an individual sample for $\delta^{15} \mathrm{~N}$ of total dissolved $\mathrm{N}, \mathrm{NH}_{4}{ }^{+}, \mathrm{NO}_{3}{ }^{-}$, and EON were $0.3,0.5,0.2$, and $1.5 \%$, respectively. 
measured with an on-line C and N analyzer (NC 2500; Thermo Fisher Scientific, Waltham, MA, USA) coupled with an isotope ratio mass spectrometer (MAT252; Thermo Fisher Scientific). The precision of the $\delta^{15} \mathrm{~N}$ measurement was $\pm 0.2 \%$.

\section{Nitrate reductase activity}

On July 9, 2017, leaves and fine root samples were collected from seven healthy Oak trees and seven above-ground shoots of Sasa in the study plot for in vivo nitrate reductase activity (NRA) assays. The samples were collected between 11:00 and 13:00 on a sunny day and kept at $4{ }^{\circ} \mathrm{C}$ for several hours before the measurement of NRA. The measurements of in vivo NRA followed the procedure described by Koyama and Tokuchi (2003), with some modification: for both species, 20 to 25 leaf disks of $10 \mathrm{~mm}$ diameter (about $200 \mathrm{mg}$ ) and fine roots (about $200 \mathrm{mg}$ ) were used.

\section{Statistical analyses}

Two-way analysis of variance (ANOVA) was used to analyze the effect of tree species, soil depths and the interactions of those variables upon fine root density. For comparison

259 of soil and fine root parameters including pool size and isotopic value of inorganic and organic $\mathrm{N}$ sources, and fine root biomass among soil depths and among tree or $\mathrm{N}$ species, we used within-subjects ANOVAs for each soil profile, because within-subjects factor with the Holm's test for multiple comparisons. Bartlett's test was conducted to test the homogeneity of variance of the data prior to the ANOVAs. If the $P$ values for the Bartlett's tests were $<0.05$, the data were log transformed prior to the ANOVA analysis. If the 
values were zero or negative, we added an integer to exceed zero before log transformation. For comparisons of leaf $\mathrm{N}$ concentration and foliar $\delta^{15} \mathrm{~N}$ between Oak and capsules and those of other $\mathrm{N}$ species at each soil depth, we used pairwise comparisons using $t$-tests with the Holm's method for the adjustment of $P$ values. For comparisons of NRA of leaves and roots between Oak and Sasa, we used the Welch's $t$-test. R software (version 3.3.3; R Development Core Team 2014) was used for all statistical analyses.

\section{Results}

Fine root distribution

The mean \pm standard deviation (SD) of total fine root biomass within the top $50 \mathrm{~cm}$ of the soil was $259.2 \pm 40.8 \mathrm{~g} \mathrm{~m}^{-2}$ and $240.6 \pm 59.8 \mathrm{~g} \mathrm{~m}^{-2}$ for Oak and Sasa, respectively. Based on two-way ANOVA, the interaction between tree species and soil depth was significant $(P<0.0047)$. The Oak fine roots were concentrated in the surface soil $(0-10$ cm depth), and their density decreased sharply with increasing soil depth (Fig. 1). In the O horizon and the surface soil (0-10 cm depth), the fine root densities of Oak were higher than those of Sasa, although the difference was marginally significant in the $0-10 \mathrm{~cm}$ soil ( $P=0.007$ and $P=0.0588$ for the $O$ horizon and $0-10 \mathrm{~cm}$, respectively). For Sasa, the fine root density decreased with the increasing soil depth, as compared of the results for Oak (Fig. 1) The fine root density of Sasa tended to be slightly higher than Oak in the 30$50 \mathrm{~cm}$ soils although the difference was marginally significant $(P=0.0817)$. 
density of mycorrhiza-infected root tips (number of mycorrhizal roots tip / unit volume of soils) of Oak are shown in Table 1.

\section{Soil $\mathbf{N}$ isotope and dynamics}

The soil weight based $\mathrm{NH}_{4}{ }^{+}$and EON contents were greater in the $\mathrm{O}$ horizon and decreased with soil depth (Fig. 2a, 3b). The soil weight based $\mathrm{NO}_{3}{ }^{-}$content was not detectable or very low irrespective of soil depths for both sampling dates (Fig. 2a, 3b). The EON pool size was higher than that of $\mathrm{NH}_{4}{ }^{+}$in the $\mathrm{O}$ horizon and at the $0-10 \mathrm{~cm}$ soil depth (Fig. 2a). The volume-based $\mathrm{N}$ pool showed a different pattern on a soil weight basis (Fig. 2b). The pool sizes of $\mathrm{NH}_{4}{ }^{+}$and EON were lower in the $\mathrm{O}$ horizon than in deeper soils, although the differences were not significant for EON (Fig. 2b).

The pool sizes of $\mathrm{NH}_{4}{ }^{+}$and $\mathrm{NO}_{3}{ }^{-}$per unit soil weight increased and the pool size of EON decreased to a much greater degree in the $\mathrm{O}$ horizon than in mineral soils during the incubation period (Fig. 2c). The volume-based net change rate of the $\mathrm{NH}_{4}{ }^{+}$pool was higher in the $\mathrm{O}$ horizon (Fig. 2d). Net change rates of the EON pool were almost negative and the difference was not significant among soil depths (Fig. 2d). The net change rate of the $\mathrm{NO}_{3}{ }^{-}$pool tended to be the highest at 0-10 $\mathrm{cm}$ soil depth and decreased with soil depth, but the differences were not significant (Fig. 2d).

The mean $\pm \mathrm{SD}$ of soil $\mathrm{NO}_{3}{ }^{-}$and $\mathrm{NH}_{4}{ }^{+}$contents captured by the ion exchange resin capsules at the $10 \mathrm{~cm}$ depth of the soils were $0.35 \pm 0.19$ and $0.30 \pm 0.22 \mathrm{mgN}$ capsule ${ }^{-1}$ year ${ }^{-1}$, respectively, indicating that $\mathrm{NO}_{3}{ }^{-}$existed in the soil solutions at a similar level as $\mathrm{NH}_{4}{ }^{+}$throughout the year, even though the soil extractable $\mathrm{NO}_{3}{ }^{-}$was not detectable or was very low on the two sampling dates. 

0-10 cm soils, and while was EON $>\mathrm{NH}_{4}{ }^{+}>$Bulk for the 10-30 $\mathrm{cm}$ soils (Fig. 3). The $\delta^{15} \mathrm{~N}$ values of Bulk, EON, and $\mathrm{NH}_{4}{ }^{+}$ranged from -4.2 to $+4.7 \%$ o, -3.5 to $+5.4 \%$, and -8.0 to $+4.7 \%$ o, respectively, all of which increased significantly with soil depth (Fig. 3a). The $\delta^{15} \mathrm{~N}$ values of $\mathrm{NH}_{4}{ }^{+}$and EON for the 30-50 cm depth could not be measured by our method due to low concentrations. The $\delta^{15} \mathrm{~N}$ value of $\mathrm{NO}_{3}{ }^{-}$also could not be measured due to low concentrations, while the $\delta^{15} \mathrm{~N}$ values of $\mathrm{NO}_{3}{ }^{-}$captured by the ion exchange resin capsules (10 $\mathrm{cm}$ in depth) were $-8.8 \pm 3.6 \%$ (mean $\pm \mathrm{SD}$ ), significantly lower than the value of other $\mathrm{N}$ forms, with the exception of the $\delta^{15} \mathrm{~N}$ value of $\mathrm{NH}_{4}{ }^{+}$of the $\mathrm{O}$ horizon (Fig. 3a).

\section{Plant leaf $\mathbf{N}$ concentration, leaf $\mathbf{N}$ isotope ratio, and NRA}

The mean \pm SD of the leaf $N$ concentrations for Oak and Sasa were $2.22 \pm 0.20$ and 2.15 $\pm 0.13 \%$, respectively, and the differences between Oak and Sasa were not significant $(t-$ test, $\mathrm{n}=7, P=0.46)$. The means $\pm \mathrm{SD}$ of foliar $\delta^{15} \mathrm{~N}$ for Oak and Sasa were $-3.77 \pm 0.83$ and $-2.61 \pm 1.16 \%$, respectively (Fig. 3a), and differences between Oak and Sasa were marginally significant ( $t$-test, $n=7, P=0.055$ ). The values approached the value of EON in the $\mathrm{O}$ horizon, but were higher than that of $\mathrm{NH}_{4}{ }^{+}$in the $\mathrm{O}$ horizon and lower than that of EON and $\mathrm{NH}_{4}{ }^{+}$at the $10-30 \mathrm{~cm}$ depth (Fig. 3a). the difference between Oak and Sasa was not significant (Fig. 4 ; $t$-test, $n=7, P=0.55$ ). between Oak and Sasa was not significant (Fig. 4; $t$-test, $n=7, P=0.12$ ). 
Discussion

339

\section{Vertical distribution of plant fine roots}

According to the vertical fine root distribution, most of the fine roots were concentrated in the surface mineral soils for both Oak and Sasa, and the roots of the species overlapped considerably, which likely induced competition for the same $\mathrm{N}$ sources between the two species. The extent of the fine root concentration in the surface mineral soils was greater in Oak than in Sasa (Fig. 1). Mycorrhizal associations differed between the two species: Oak was associated with ectomycorrhizal fungi (Obase et al. 2007), but Sasa was not (Fukuchi et al. 2011). Lindahl et al. (2007) suggested that ectomycorrhizal mycelium dominated in the decomposed litter and humus horizon in coniferous boreal forests. The fine root biomass of Oak was concentrated in the surface mineral soil (0-10 cm depth), just below the $\mathrm{O}$ horizon (Fig. 1), and mycorrhizal root tips were also found in greater density in surface mineral soils. Anderson et al. (2014) reported that fine-scale distribution patterns along a soil profile were different between mycorrhizal root tips and mycelium. However, these findings were derived from coniferous boreal forests, and may not be directly applicable to a broad-leaved forest dominated by the ectomycorrhizal tree species. We speculated that a considerable portion of the ectomycorrhizal mycelium associated with Oak trees may extend from the roots in surface mineral soils into the $\mathrm{O}$ horizon. Compared with Oak, Sasa tended to distribute more fine roots in deeper soils decomposition ability of arbuscular mycorrhizal fungi is lower than that of 
ectomycorrhizal fungi (Courty et al. 2010). However, the mycorrhizal infection of Sasa was not analyzed in this study. Further study of mycorrhizal infection on root tips and the mycelial distribution pattern of both species would help to clarify the detailed mechanisms of $\mathrm{N}$ competition and $\mathrm{N}$ foraging by mycorrhizal fungi. In spite of these limitations, our results indicate the competitive advantage of Oak in the nutrient rich $\mathrm{O}$ horizon and surface mineral soils, whereas Sasa might avoid soil N resource competition by foraging in deeper soils.

\section{Isotopic evidence of $\mathbf{N}$ utilization of co-existing canopy and understory vegetation}

The $\delta^{15} \mathrm{~N}$ value of possible $\mathrm{N}$ sources varied widely among $\mathrm{N}$ species as well as among soil depths. The $\delta^{15} \mathrm{~N}$ value of Bulk, $\mathrm{NH}_{4}{ }^{+}$, and EON increased with soil depth, consistent with the results of previous studies (Koba et al. 1998, 2010, 2012; Hobbie and Ouimette 2009; Brearley 2013). Dependence on shallower N sources results in lower N isotope ratios in plants (Kohzu et al. 2003). Although the difference was marginally significant $(P=0.055)$, the $\delta^{15} \mathrm{~N}$ value of Oak leaves was slightly lower than that of Sasa, indicating that Oak may depend on shallower $\mathrm{N}$ source. Furthermore, N species are also an important determinant for plant $\delta^{15} \mathrm{~N}$ value (Nadelhoffer et al. 1996; Högberg 1997; Koba et al. 2003; Tateno et al. 2005; Houlton et al. 2007; Craine et al. 2015; Liu et al. 2018). The order of the $\delta^{15} \mathrm{~N}$ value of the soils was EON $>$ Bulk $>\mathrm{NH}_{4}{ }^{+}$at this study site which was consistent with previous reports (Houlton et al. 2007; Koba et al. 2010, 2012).

The $\delta^{15} \mathrm{~N}$ value of soil $\mathrm{NO}_{3}{ }^{-}$could not be measured owing to an extremely low pool size, but the $\delta^{15} \mathrm{~N}$ of soil $\mathrm{NO}_{3}{ }^{-}$is typically much lower than that of $\mathrm{NH}_{4}{ }^{+}$and EON (Koba et al. 1998, 2010, 2012; Tanaka-Oda et al. 2016; Liu et al. 2018). The $\delta^{15} \mathrm{~N}$ value 
of $\mathrm{NO}_{3}{ }^{-}$captured by the ion exchange resin capsules was lower than that of the other sources. Positive net production rates of $\mathrm{NO}_{3}{ }^{-}$were observed (Fig. 2d). $\mathrm{NO}_{3}{ }^{-}$was available to plants above and below $10 \mathrm{~cm}$ mineral soil depth, and acquisition of soil $\mathrm{NO}_{3}{ }^{-}$ lead to ${ }^{15} \mathrm{~N}$-depletion in the plants even when the measurable pool sizes of the extractable $\mathrm{NO}_{3}{ }^{-}$were very low (Fig. 2a, c). However, the negligible NRA of Oak (Fig. 4) suggests low dependence on $\mathrm{NO}_{3}{ }^{-}$at this site, although Quercus serrata, Quercus robur, and Quercus petraea have been shown to have NRA capability in other regions (Truax et al. 1994; Thomas and Hilker 2000; Schmull and Thomas 2000; Takahashi et al. 2005). This may be partly due to extremely low $\mathrm{NO}_{3}{ }^{-}$supply rates in this study site because NRA is known as a substrate-induced reaction (Beevers and Hageman 1969). The NRA of Sasa leaves was negligible, but the NRA in the roots of some individuals was far higher than that of Oak, although the difference of mean root NRA between the two species was not significant $(P=0.12)$. Large variations in root NRA for Sasa may have been due to individual variations in accessibility of the soil $\mathrm{NO}_{3}{ }^{-}$just before the sampling timing. This result may indicate that $\mathrm{NO}_{3}{ }^{-}$assimilation of Sasa primarily takes place in the roots rather than in the leaves, if the roots can access soil $\mathrm{NO}_{3}{ }^{-}$sources. $\mathrm{Root} \mathrm{NO}_{3}{ }^{-}$assimilation of understory species was also reported by Oliveira et al. (2017), suggesting that it might have an adaptive advantage in shady environments because $\mathrm{N}$ assimilation would compete with carbon assimilation in the leaves (Bloom et al. 2010).

Soil $\mathrm{NH}_{4}{ }^{+}$(particularly in the $\mathrm{O}$ horizon) was the second ${ }^{15} \mathrm{~N}$-depleted $\mathrm{N}$ source; acquisition of this $\mathrm{N}$ source can lead to ${ }^{15} \mathrm{~N}$-depletion in plants, while utilization of EON and $\mathrm{NH}_{4}{ }^{+}$in deeper soils can lead to ${ }^{15} \mathrm{~N}$-enrichment in plants. Previous studies have reported that plants can take up organic N as an N source (Näsholm et al. 1998, 2009), while report of $\delta^{15} \mathrm{~N}$ value of EON have been very limited until recently (Houlton et al. 
2007; Takebayashi et al. 2010; Koba et al. 2010, 2012). In right of the ectomycorrhizal associations and low NRA (Fig. 4), it is likely that Oak used both $\mathrm{NH}_{4}{ }^{+}$and EON in the O horizon and surface mineral soils. In this study, we did not specify the chemical composition of EON, which can include easily decomposing substrates and recalcitrant substrates; further study is needed to reveal the $\mathrm{N}$ source utilization of ectomycorrhizal species through determining the chemical composition of EON. In contrast to Oak, Sasa had high NRA, particularly in the roots (Fig. 4), suggesting that it utilized $\mathrm{NO}_{3}{ }^{-}$from surface and deep mineral soils and used $\mathrm{NH}_{4}{ }^{+}$as a counter source of enriched $\delta^{15} \mathrm{~N}$. Thus, the understory dwarf bamboo, Sasa, mitigated soil $\mathrm{N}$ competition against co-existing canopy trees not only by foraging in deeper soils, but also by increasing its dependence on $\mathrm{N}$ forms different than those used by the canopy trees.

\section{Limitation of this study and possible effects of $\mathbf{N}$ source utilization of plants on ecosystem functions}

Due to the simple vegetation composition of our study sites, which primarily contained one species of canopy tree and one species of understory vegetation, the ecosystem-scale implications of our findings may not directly scale to more diverse ecosystems due to variation in the timing of $\mathrm{N}$ uptake between different functional types of plant species (Larsen et al 2012). However, our results aid in understanding the $\mathrm{N}$ cycling of the typical vegetation in the study area (Watanabe et al. 2019; Tateno et al. 2019).

At this study site, $\mathrm{NO}_{3}{ }^{-}$pool sizes were relatively small (Fig. 2 and 3b). However, considerable gross $\mathrm{NO}_{3}{ }^{-}$production occurred in forests adjacent to our study site (Hosokawa et al. 2017; Watanabe et al. 2019), as compared with other regions from 38 
433 sites across the Japanese archipelago (Urakawa et al. 2015). Furthermore, ammonia 434 oxidizing archaea were found throughout the growing season in these adjacent forests 435 (Isobe et al. 2018). Thus, $\mathrm{NO}_{3}{ }^{-}$could be an important $\mathrm{N}$ source at this study site, although 436 Oak may not be an effective user of $\mathrm{NO}_{3}{ }^{-}$as interpreted in the earlier section on NRA analysis and isotopic evidence. The importance of understory Sasa senanensis Rehder for the $\mathrm{N}$ leaching process has been reported in the northern hardwood forest ecosystems of northern Japan (Fukuzawa et al. 2006, 2015). For example, Fukuzawa et al. (2006) reported that existence of $S$. senanensis considerably reduced $\mathrm{NO}_{3}{ }^{-}$leaching via stream water after forest clear cutting; about $59-88 \%$ of fine root biomass and about $30 \%$ of litterfall was accounted for by S. senanensis (Fukuzawa et al. 2013; Watanabe et al. 2013). In this study site, Sasa likely took up $\mathrm{NO}_{3}{ }^{-}$as interpreted in the earlier section on root NRA analysis, although further study of the detailed seasonality of NRA in Sasa and Oak is needed to confirm this assertion.

\section{Conclusions}

Although leaf $\delta^{15} \mathrm{~N}$ values did not significantly differ between Oak and Sasa, dependence on $\mathrm{N}$ source can be assumed to differ between the two species due to differences in their morphological, physiological, and mycorrhizal properties. Based on the results of the vertical distribution of fine roots and the soil $\mathrm{N}$ pool, the $\delta^{15} \mathrm{~N}$ of leaves and possible soil $\mathrm{N}$ sources, and the NRA of the fine roots, Oak would primarily use $\mathrm{NH}_{4}{ }^{+}$and organic $\mathrm{N}$ in the $\mathrm{O}$ horizon and/or surface soils, while Sasa would likely utilize the $\mathrm{N}$ in deeper soils and $\mathrm{NO}_{3}{ }^{-}$. Our findings therefore indicate that co-existing canopy tree species and understory species in a cool-temperate forest in northern Japan have N sources of different $\mathrm{N}$ forms, from different soil depths. 
458 Author contribution statement RT, KF, YI, KK, and SU designed the study and

conducted sampling and pretreatments for isotopic measurements. RT and MN conducted soil chemical analyses and NRA measurement, and RT, MN, and KF conducted fine root analyses. MY, YI, and KK conducted isotopic measurements. RT wrote the paper and all authors have critically reviewed the manuscript.

463

Acknowledgements

We thank members of the for Hokkaido Forest station, Field Science Education and

466 Research Center, Kyoto University for cooperation and logistics at the field site and 467 laboratory. We also thank to Dr. Keitaro Fukushima and Ms. Chikae Tatsumi and the members of Center for Ecological Research, Kyoto University and FFPRI for isotope measurements. This work was supported by JSPS-KAKENHI (NO. 26292085, 16H04937, and 18H02241). This work was also supported by Joint Usage / Research Grant of Center for Ecological Research, Kyoto University. We would like to thank Editage (www.editage.jp) for English language editing.

Compliance with ethical standards

475 Conflict of interest The authors declare that they have no conflict of interest. 
477

478

479

480

481

482

483

484

485

486

487

488

489

490

491

492

493

494

495

496

497

498

499

500

501

502

503

504

505

506

507

508

509

510

511

\section{References}

Anderson IC, Genney DR, Alexander IJ (2014) Fine - scale diversity and distribution of ectomycorrhizal fungal mycelium in a Scots pine forest. New Phytol 201:14231430

Averill C, Turner BL, Finzi AC (2014) Mycorrhiza-mediated competition between plants and decomposers drives soil carbon storage. Nature 505:543-545

Beevers L, Hageman RH (1969) Nitrate reduction in higher plants. Annu Rev Plant Physiol 20:495-522.

Bloom AJ, Burger M, Asensio JSR, Cousins AB (2010) Carbon dioxide enrichment inhibits nitrate assimilation in wheat and Arabidopsis. Science, 328:899-903.

Brearley FQ (2013) Nitrogen stable isotopes indicate differences in nitrogen cycling between two contrasting Jamaican montane forests. Plant Soil 367:465-476

Cardinael R, Mao Z, Prieto I, Stokes A, Dupraz C, Kim JH, Jourdan C (2015) Competition with winter crops induces deeper rooting of walnut trees in a Mediterranean alley cropping agroforestry system. Plant Soil 391: 219-235

Casciotti KL, Sigman DM, Hastings MG, Böhlke JK, Hilkert A. (2002) Measurement of the oxygen isotopic composition of nitrate in seawater and freshwater using the denitrifier method. Anal Chem 74: 4905-4912

Chalot M, Brun A (1998) Physiology of organic nitrogen acquisition by ectomycorrhizal fungi and ectomycorrhizas. FEMS Microbiol Rev 22:21-44

Courty PE, Buée M, Diedhiou AG, Frey-Klett P, Le Tacon F, Rineau F, Turpault MP, Uroz S, Garbaye J (2010) The role of ectomycorrhizal communities in forest ecosystem processes: New perspectives and emerging concepts. Soil Biol Biochem 42:679-698

Craine JM, Brookshire ENJ, Cramer MD, Hasselquist NJ, Koba K, Marin-Spiotta E, Wang L (2015) Ecological interpretations of nitrogen isotope ratios of terrestrial plants and soils. Plant Soil 396:1-26

Debiasi TV, Calzavara AK, da Silva LM, da Silva JG, Bianchini E, Pimenta JA, Stolf-Moreira R, Aidar MPM, Sodek L, Oliveira HC (2019) Nitrogen metabolism of Neotropical tree seedlings with contrasting ecological characteristics. Acta Physiol Plant 41: 131

DeLuca T, Nilsson MC, Zackrisson O (2002) Nitrogen mineralization and phenol accumulation along a fire chronosequence in northern Sweden. Oecologia, 133:206-214

Downs MR, Nadelhoffer KJ, Melillo JM, Aber JD (1993) Foliar and fine root nitrate 
512

513

514

515

516

517

518

519

520

521

522

523

524

525

526

527

528

529

530

531

532

533

534

535

536

537

538

539

540

541

542

543

544

545

546

reductase activity in seedlings of four forest tree species in relation to nitrogen availability. Trees-Struct Funct 7:233-236

Evans RD (2001) Physiological mechanisms influencing plant nitrogen isotope composition. Trends Plant Sci 6:121-126

Fukuchi S, Obase K, Tamai Y, Yajima T, Miyamoto T (2011) Vegetation and colonization status of mycorrhizal and endophytic fungi in plant species on acidic barren at crater basin of volcano Esan in Hokkaido, Japan. Eurasian J For Res 14:1-11

Fukuzawa K, Shibata H, Takagi K, Nomura M, Kurima N, Fukazawa T, Satoh F, Sasa K (2006) Effects of clear-cutting on nitrogen leaching and fine root dynamics in a cool-temperate forested watershed in northern Japan. For Ecol Manage 225:257-261

Fukuzawa K, Shibata H, Takagi K, Satoh F, Koike T, Sasa K (2015) Roles of dominant understory Sasa bamboo in carbon and nitrogen dynamics following canopy tree removal in a cool-temperate forest in northern Japan. Plant Species Biol 30:104115

Fukuzawa K, Shibata H, Takagi K, Satoh F, Koike T, Sasa K (2013) Temporal variation in fine-root biomass, production and mortality in a cool temperate forest covered with dense understory vegetation in northern Japan. For Ecol Manage 310:700710

Gherardi LA, Sala OE, Yahdjian L (2013) Preference for different inorganic nitrogen forms among plant functional types and species of the Patagonian steppe. Oecologia 173:1075-1081

Hiura T (2001) Stochasticity of species assemblage of canopy trees and understorey plants in a temperate secondary forest created by major disturbances. Ecol Res 16:887-893

Hobbie EA, Macko SA, Williams M (2000) Correlations between foliar delta ${ }^{15} \mathrm{~N}$ and nitrogen concentrations may indicate plant-mycorrhizal interactions. Oecologia 122: $273-283$

Hobbie EA, Ouimette AP (2009) Controls of nitrogen isotope patterns in soil profiles. Biogeochemistry 95:355-371

Hobbie EA, Högberg H (2012) Nitrogen isotopes link mycorrhizal fungi and plants to nitrogen dynamics. New Phytol 196:367-382

Hodge A, Campbell CD, Fitter AH (2001) An arbuscular mycorrhizal fungus accelerates decomposition and acquires nitrogen directly from organic material. Nature 413:297-299 
547

548

549

550

551

552

553

554

555

556

557

558

559

560

561

562

563

564

565

566

567

568

569

570

571

572

573

574

575

576

577

578

579

580

581

Högberg P (1997) Tansley review no. $95{ }^{15} \mathrm{~N}$ natural abundance in soil-plant systems. New Phytol 137:179-203

Holmes RM, McClelland JW, Sigman DM, Fry B, Peterson BJ (1998) Measuring ${ }^{15} \mathrm{~N}-$ $\mathrm{NH}^{4+}$ in marine, estuarine and fresh waters: An adaptation of the ammonia diffusion method for samples with low ammonium concentrations. Mar Chem 60:235-243

Hosokawa N, Isobe K, Urakawa R, Tateno R, Fukuzawa K, Watanabe T, Shibata H (2017) Soil freeze-thaw with root litter alters $\mathrm{N}$ transformations during the dormant season in soils under two temperate forests in northern Japan. Soil Biol Biochem $114: 270-278$

Houlton BZ, Sigman DM, Schuur EA, Hedin LO (2007) A climate-driven switch in plant nitrogen acquisition within tropical forest communities. Proc. Natl. Acad. Sci. U.S.A. 104:8902-8906

Isobe K, Oka H, Watanabe T, Tateno R, Urakawa R, Liang C, Senoo K, Shibata H (2018) High soil microbial activity in the winter season enhances nitrogen cycling in a cool-temperate deciduous forest. Soil Biol Biochem 124:90-100

IUSS Working group WRB (2015) World reference base for soil resources 2014 (Update 2015), International soil classification system for naming soils and creating legends for soil maps. World Soil Resources Reports No. 106. FAO, Rome

Kayama M, Koike T (2017) Growth characteristics of dwarf bamboo distributed in the northern part of Japan. In: Abdul Khalil HPS(ed) Bamboo-Current and Future Prospects. IntechOpen, London. pp 185-199.

Keeney DR, Nelson DW (1982) Nitrogen-inorganic forms. In: Page AL, Miller RH, Keeney DR (eds) Methods of soil analysis part 2. American Society of Agronomy. Madison, Wisconsin. pp 643-698.

Koba K, Tokuchi N, Yoshioka T, Hobbie EA, Iwatsubo G (1998) Natural abundance of nitrogen-15 in a forest soil. Soil Sci Soc Am J 62: 778-781

Koba K, Hirobe M, Koyama L, Kohzu A, Tokuchi N, Nadelhoffer KJ, Wada E, Takeda $\mathrm{H}$ (2003) Natural ${ }^{15} \mathrm{~N}$ abundance of plants and soil $\mathrm{N}$ in a temperate coniferous forest. Ecosystems 6: 457-469

Koba K, Isobe K, Takebayashi Y, et al (2010) Delta ${ }^{15} \mathrm{~N}$ of soil $\mathrm{N}$ and plants in a Nsaturated, subtropical forest of southern China. Rapid Commun Mass Spectrom 24:2499-2506

Koba K, Fang Y, Mo J, et al (2012) The ${ }^{15} \mathrm{~N}$ natural abundance of the $\mathrm{N}$ lost from an Nsaturated subtropical forest in southern China. J Geophys Res 117:G02015 
582

583

584

585

586

587

588

589

590

591

592

593

594

595

596

597

598

599

600

601

602

603

604

605

606

607

608

609

610

611

612

613

614

615

616

Koyama L, Tokuchi N (2003) Effects of $\mathrm{NO}_{3}{ }^{-}$availability on $\mathrm{NO}_{3}{ }^{-}$use in seedlings of three woody shrub species. Tree Physiol 23: 281-288

Kronzucker HJ, Siddiqi MY, Glass AD (1997) Conifer root discrimination against soil nitrate and the ecology of forest succession. Nature 385:59-61

Lee JA, Stewart GR (1978) Ecological aspects of nitrogen assimilation. Adv Bot Res 6: $1-43$

Lei TT, Koike T (1998) Functional leaf phenotypes for shaded and open environments of a dominant dwarf bamboo (Sasa senanensis) in northern Japan. Int J Plant Sci 159:812-820

Lindahl BD, Ihrmark K, Boberg J, Trumbore SE, Högberg P, Stenlid J, Finlay RD (2007) Spatial separation of litter decomposition and mycorrhizal nitrogen uptake in a boreal forest. New Phytol 173:611-620

Liu XY, Koba K, Koyama L, et al (2018) Nitrate is an important nitrogen source for Arctic tundra plants. Proc. Natl. Acad. Sci. U.S.A. 115:3398-3403

McIlvin MR, Casciotti KL (2011) Technical updates to the bacterial method for nitrate isotopic analyses. Anal Chem 83:1850-1856.

Mayor J, Bahram M, Henkel T, Buegger F, Pritsch K, Tedersoo L (2015) Ectomycorrhizal impacts on plant nitrogen nutrition: emerging isotopic patterns, latitudinal variation and hidden mechanisms. Ecol Lett 18:96-107

Nadelhoffer K, Shave G, Fry B, Giblin A, Johnson L, McKane R (1996) ${ }^{15} \mathrm{~N}$ natural abundances and $\mathrm{N}$ use by tundra plants. Oecologia 107: 386-394

Nakayama M, Tateno R (2018) Solar radiation strongly influences the quantity of forest tree root exudates. Trees-Struct Funct 32:871-879

Näsholm T, Ekblad A, Nordin A, Giesler R, Högberg M, Högberg P (1998) Boreal forest plants take up organic nitrogen. Nature 392:914-916

Näsholm T, Kielland K, Ganeteg U (2009). Uptake of organic nitrogen by plants. New Phytol 182:31-48

Obase K, Tamai Y, Yajima T, Miyamoto T (2007) Mycorrhizal associations in woody plant species at the Mt. Usu volcano, Japan. Mycorrhiza 17:209-215

Oliveira HC, da Silva LMI, de Freitas LD, Debiasi TV, Marchiori NM, Aidar MPM, Bianchini E, Pimenta JA, Stolf-Moreira R (2017) Nitrogen use strategies of seedlings from neotropical tree species of distinct successional groups. Plant Physiol Biochem 114:119-127

Nordin A, Högberg P, Näsholm T (2001) Soil nitrogen form and plant nitrogen uptake along a boreal forest productivity gradient. Oecologia 129:125-132 
617

618

619

620

621

622

623

624

625

626

627

628

629

630

631

632

633

634

635

636

637

638

639

640

641

642

643

644

645

646

647

648

649

650

651

Phillips RP, Brzostek E, Midgley MG (2013) The mycorrhizal-associated nutrient economy: a new framework for predicting carbon-nutrient couplings in temperate forests. New Phytol 199:41-51

Schimel JP, Bennett J (2004) Nitrogen mineralization: challenges of a changing paradigm. Ecology 85:591-602

Schmull M, Thomas FM (2000) Morphological and physiological reactions of young deciduous trees (Quercus robur L., Q. petraea [Matt.] Liebl., Fagus sylvatica L.) to waterlogging. Plant Soil 225:227-242

Sigman DM, Casciotti KL, Andreani M, Barford C, Galanter M, Böhlke J (2001) A bacterial method for the nitrogen isotopic analysis of nitrate in seawater and freshwater. Anal Chem 73:4145-4153

Smith SE, Smith FA (2011) Roles of arbuscular mycorrhizas in plant nutrition and growth: new paradigms from cellular to ecosystem scales. Annu Rev Plant Biol 62:227250

Takahashi M, Higaki A, Nohno M, Kamada M, Okamura Y, Matsui K, Kitani S, Morikawa H (2005) Differential assimilation of nitrogen dioxide by 70 taxa of roadside trees at an urban pollution level. Chemosphere 61:633-639

Takebayashi Y, Koba K, Sasaki Y, Fang Y, Yoh M (2010) The natural abundance of ${ }^{15} \mathrm{~N}$ in plant and soil-available $\mathrm{N}$ indicates a shift of main plant $\mathrm{N}$ resources to $\mathrm{NO}_{3}{ }^{-}$ from $\mathrm{NH}_{4}^{+}$along the $\mathrm{N}$ leaching gradient. Rapid Commun Mass Spectrom 24:1001-1008

Tanaka-Oda A, Kenzo T, Inoue Y, Yano M, Koba K, Ichie T (2016) Variation in leaf and soil $\delta^{15} \mathrm{~N}$ in diverse tree species in a lowland dipterocarp rainforest, Malaysia. Trees-Struct Funct 30:509-522.

Tateno R, Osada N, Terai M, Tokuchi N, Takeda H (2005) Inorganic nitrogen source utilization by Fagus crenata on different soil types. Trees-Struct Funct 19:477481

Tateno R, Imada S, Watanabe T, Fukuzawa K, Shibata H (2019) Reduced snow cover changes nitrogen use in canopy and understory vegetation during the subsequent growing season. Plant Soil 438:157-172

Thomas FM, Hilker C (2000) Nitrate reduction in leaves and roots of young pedunculate oaks (Quercus robur) growing on different nitrate concentrations. Environ Exper Bot 43:19-32

Truax B, Lambert F, Gagnon D, Chevrier N (1994) Nitrate reductase and glutamine synthetase activities in relation to growth and nitrogen assimilation in red oak 
652

653

654

655

656

657

658

659

660

661

662

663

664

665

and red ash seedlings: effects of $\mathrm{N}$-forms, $\mathrm{N}$ concentration and light intensity. Trees-Struct Funct 9:12-18

Urakawa R, Ohte N, Shibata H, et al (2015) Biogeochemical nitrogen properties of forest soils in the Japanese archipelago. Ecol Res 30:1-2

Vitousek PM, Howarth RW (1991) Nitrogen limitation on land and in the sea: How can it occur? Biogeochemistry 13: 87-115

Watanabe T, Fukuzawa K, Shibata H (2013) Temporal changes in litterfall, litter decomposition and their chemical composition in Sasa dwarf bamboo in a natural forest ecosystem of northern Japan. J For Res 18:129-138

Watanabe T, Tateno R, Imada S, et al (2019) The effect of a freeze-thaw cycle on dissolved nitrogen dynamics and its relation to dissolved organic matter and soil microbial biomass in the soil of a northern hardwood forest.

Biogeochemistry 142:319-338 
666 Table 1 Mean \pm SD of mycorrhizal infection ratio and mycorrhizal root tip density of 667 Quercus crispula (Oak) along the soil profile. Differences in lowercase letters indicate 668 significant differences among soil layers $(p<0.05)$ based on results of multiple 669 comparison tests with Holm's adjustment.

\begin{tabular}{lcc}
\hline & $\begin{array}{c}\text { Mycorrhizal infection } \\
\text { ratio (\%) }\end{array}$ & $\begin{array}{c}\text { Mycorrhizal root tip } \\
\text { density }\left(\mathrm{cm}^{-3}\right)\end{array}$ \\
\hline O horizon & $88.89 \pm 3.38_{\mathrm{a}}$ & $2.20 \pm 1.06_{\mathrm{bc}}$ \\
$0-10 \mathrm{~cm}$ & $69.57 \pm 2.39_{\mathrm{b}}$ & $8.40 \pm 1.74_{\mathrm{a}}$ \\
$10-30 \mathrm{~cm}$ & $61.66 \pm 7.24_{\mathrm{b}}$ & $1.57 \pm 0.52_{\mathrm{b}}$ \\
$30-50 \mathrm{~cm}$ & $77.45 \pm 9.72_{\mathrm{ab}}$ & $0.76 \pm 0.39_{\mathrm{c}}$ \\
\hline
\end{tabular}

670 
671

672

673

674

675

676

677

678

679

680

681

682

683

684

685

686

687

688

689

690

691

692

693

694

\section{Figure legends}

Fig. 1 Mean $\pm \operatorname{SD}(n=5)$ of vertical distribution of fine root density along the soil profile of Quercus crispula (Oak) and Sasa nipponica (Sasa). Differences in lowercase letters mean significant differences among soil layers for each species $(p<0.05)$ based on results of multiple comparison tests with Holm's adjustment. Symbols with brackets indicate significance levels of the paired $t$-test for tree species at each depth $(P<0.01$ and $P<0.1$ for $* *$ and + , respectively).

Fig. 2 (a, b) Soil nitrogen (N) pool on August 23, 2017 and (c, d) net N pool change of dissolved $\mathrm{N}\left(\mathrm{NH}_{4}{ }^{+}, \mathrm{NO}_{3}{ }^{-}\right.$, and extractable organic $\left.\mathrm{N}(\mathrm{EON})\right)$ in soil weight basis and volume basis, respectively. The net $\mathrm{N}$ pool changes were calculated by subtracting the pool size of each $\mathrm{N}$ species after the incubation period from initial pool size and expressed as per day values by dividing by the incubation period (28 d). Data are presented as mean \pm SD $(n=6)$. Lowercase letters indicate significant differences among soil layers and uppercase letters indicate significant differences among $\mathrm{N}$ species $(p<0.05)$ based on results of multiple comparison tests with Holm's adjustment.

Fig. 3 (a) Nitrogen (N) isotope ratios of plant leaves, bulk soils and extracts from soils and ion exchange resin capsules buried at $10 \mathrm{~cm}$ depth, and (b) soil $\mathrm{N}$ pool for extracts from soils of isotope measurement collected on July 30, 2016. Data are presented as mean $\pm \mathrm{SD}$ ( $n=5$ and 7) for $\delta^{15} \mathrm{~N}$ value of resin and leaf samples, respectively. $n=4$ for each $\mathrm{N}$ pool and $\delta^{15} \mathrm{~N}$ values of soil extracts at each horizon; $n=3$ for $\delta^{15} \mathrm{~N}$ of $\mathrm{NH}_{4}{ }^{+}$and extractable organic $\mathrm{N}(\mathrm{EON})$ at 10-30 cm horizon. Lowercase letters indicate significant 
695 differences among soil layers and uppercase letters indicate significant differences among

$696 \mathrm{~N}$ species $(p<0.05)$ based on results of multiple comparison tests with Holm's 697 adjustment..

698

699 Fig. 4 Boxplot $(n=7)$ of nitrate reductase activity (NRA) in leaves and fine roots of 700 Quercus crispula (Oak) and Sasa nipponica (Sasa). Each box shows the lower quartile, 701 median and upper quartile. Each whisker extends from each quartile to the outermost 702 point that does not extend beyond the upper or lower quartile by a value more than 1.5 703 times the interquartile range. 
Fine root density $\left(\mathrm{mg} \mathrm{cm}^{-3}\right)$

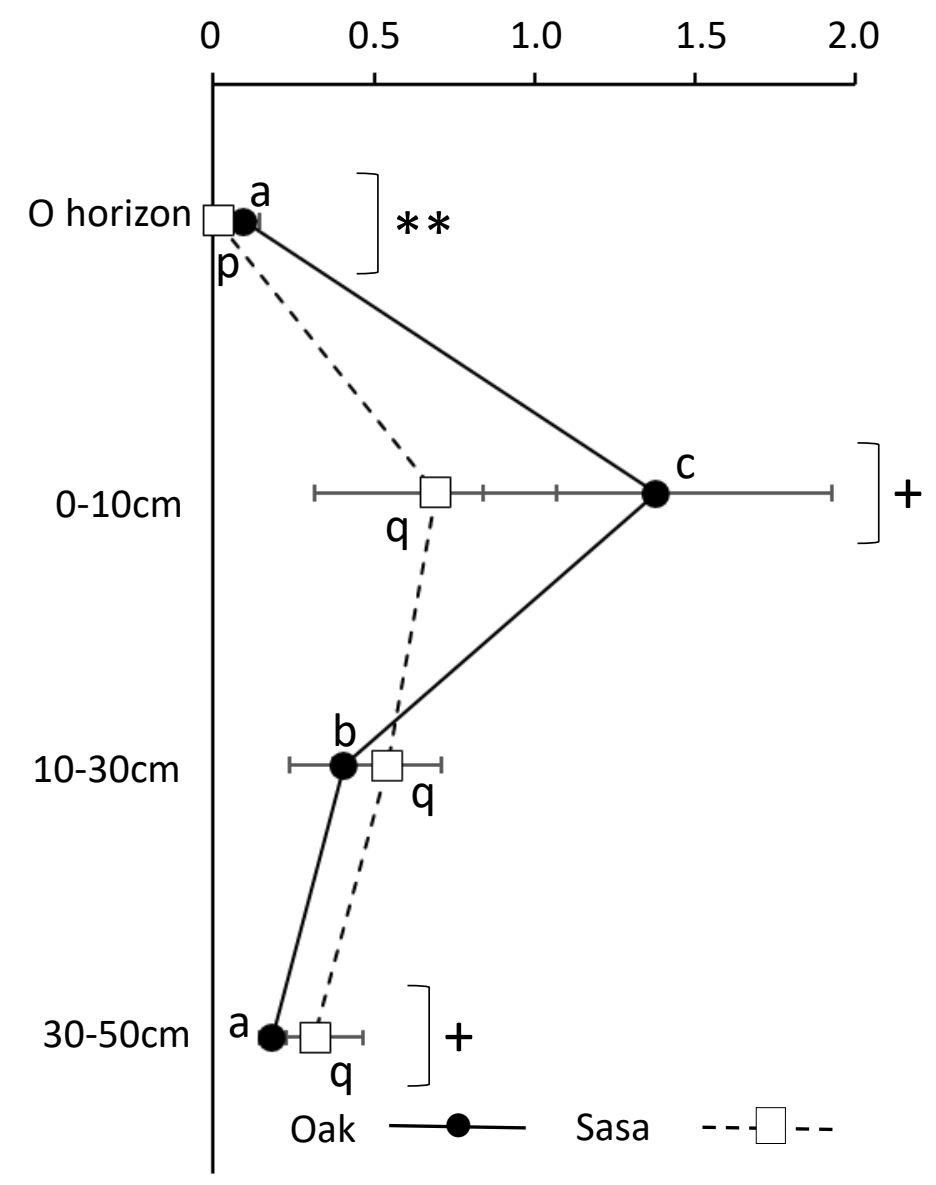




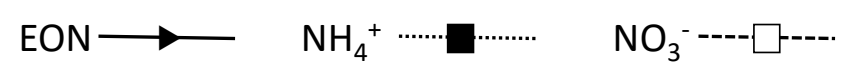

(a) $\quad \mathrm{N}$ pool $\left(\mathrm{mgN} \mathrm{kg}^{-1}\right)$

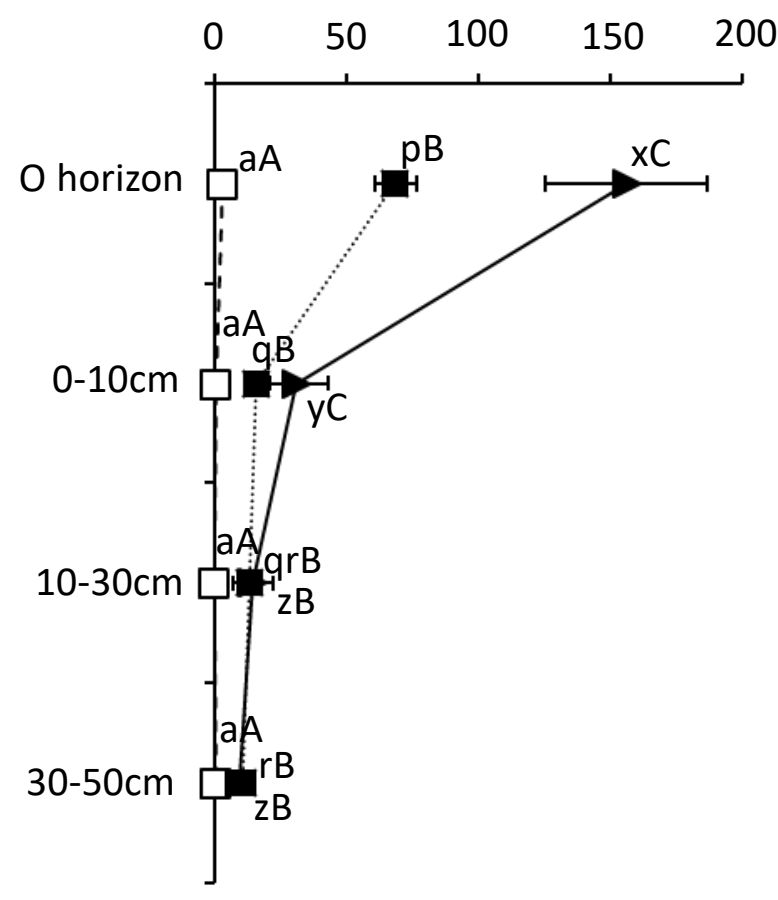

(b)

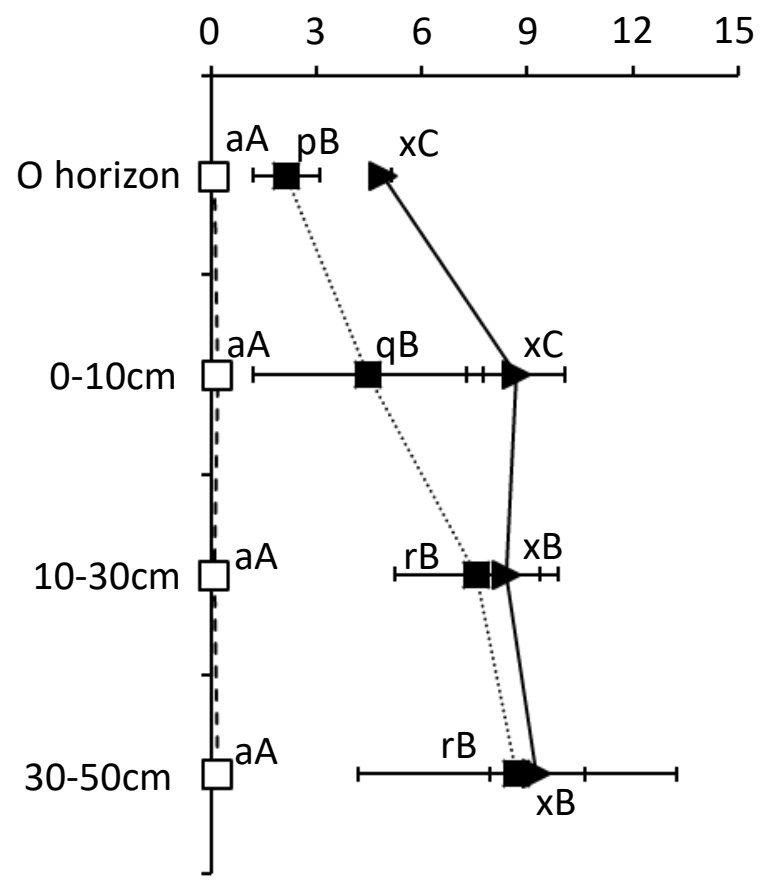

(C) Net $\mathrm{N}$ pool change $\left(\mathrm{mgN} \mathrm{kg}^{-1} \mathrm{~d}^{-1}\right)$

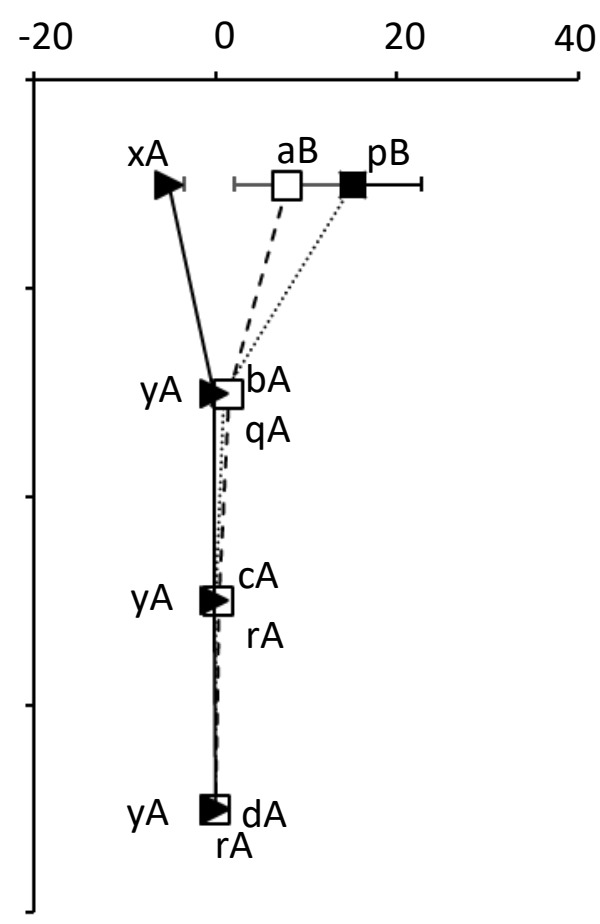

(d) Net $\mathrm{N}$ pool change $\left(\mathrm{gN} \mathrm{m}^{-3} \mathrm{~d}^{-1}\right)$

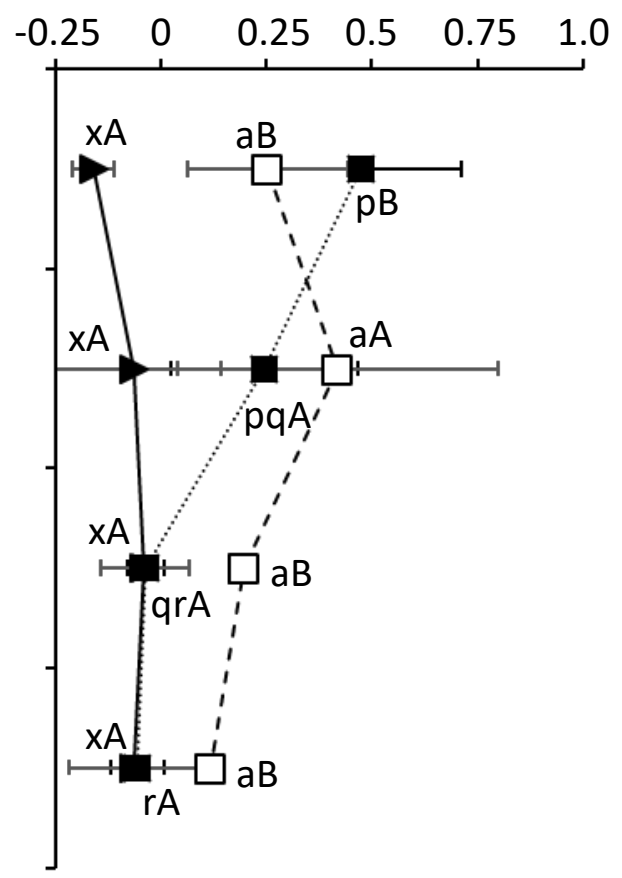


(a)

$$
\delta^{15} \mathrm{~N}(\%)
$$

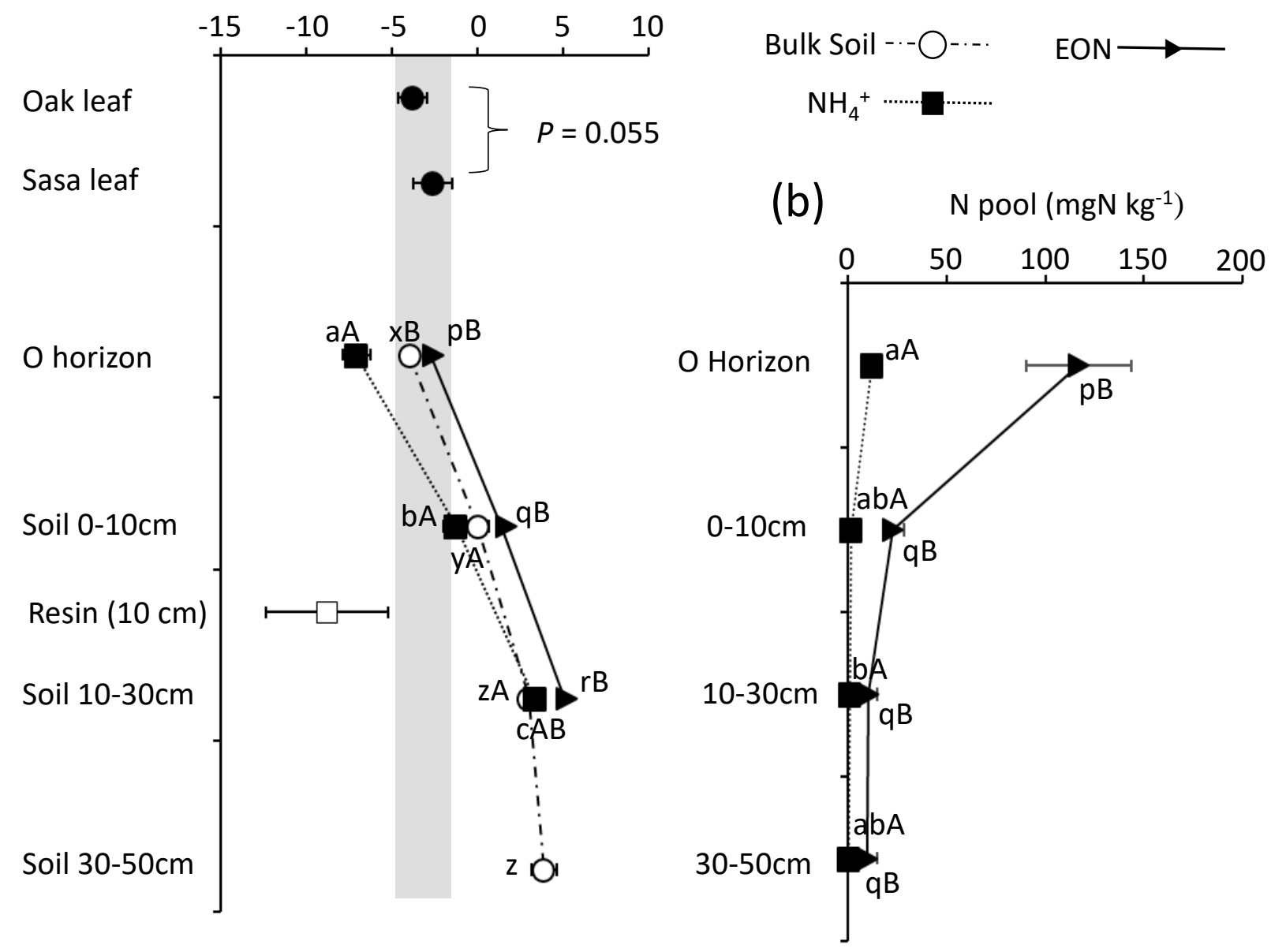




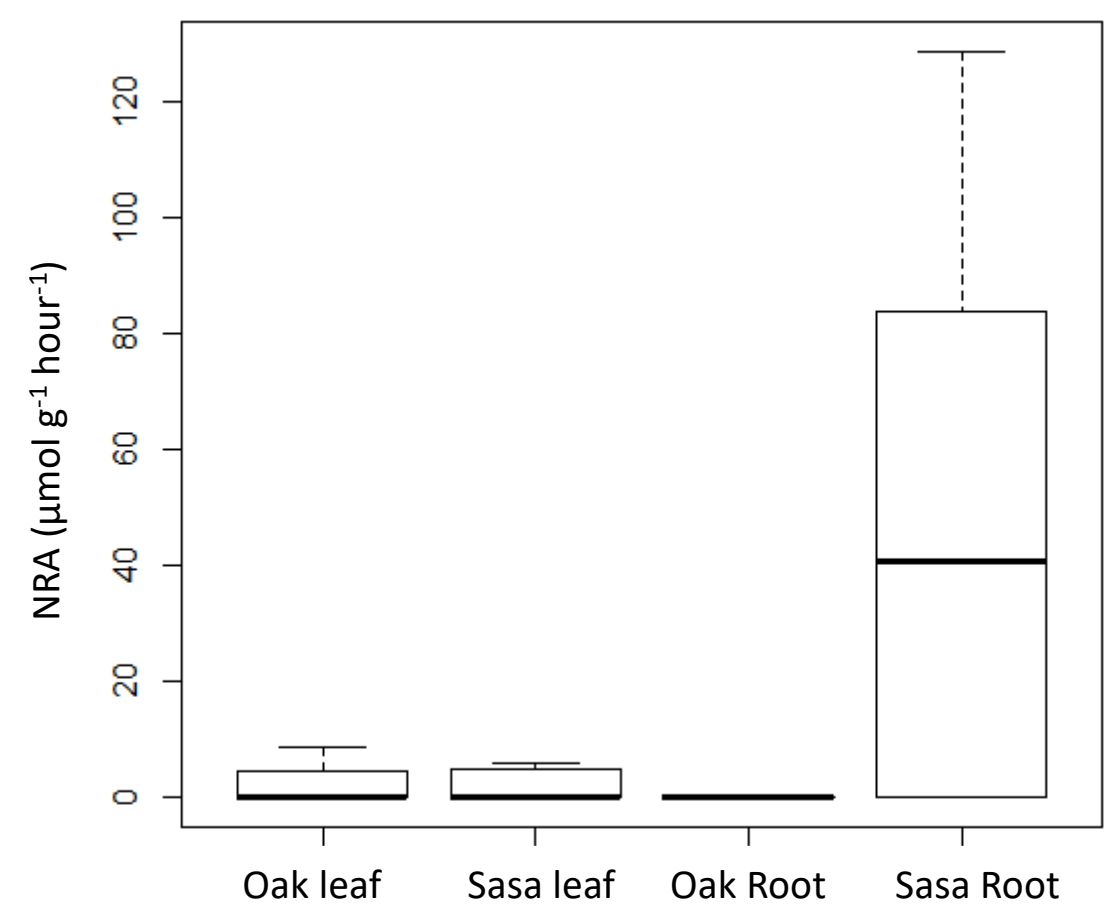

